\title{
Genetic analysis of two Portuguese populations of Ruditapes decussatus by RAPD profiling
}

\author{
Jorge C. Pereira $\cdot$ Raquel Chaves $\cdot$ Alexandra Leitão • \\ Domitilia Matias $\cdot$ Henrique Guedes-Pinto
}

Received: 4 December 2009/Revised: 22 September 2010/Accepted: 29 September 2010/Published online: 19 October 2010

(C) Springer-Verlag and AWI 2010

\begin{abstract}
The clam Ruditapes decussatus is commercially important in the south of Portugal. The random amplified polymorphic DNA (RAPD) technique was applied to assess the genetic diversity and population structure of two Portuguese populations occurring in the Ria Formosa (Faro) and the Ria de Alvor, respectively. Twenty-five individuals of each population were investigated by RAPD profiles. Genetic diversity within populations, measured by the percentage of polymorphic loci $(\% P)$, varied between $68.57 \%$ (Alvor) and $73.88 \%$ (Faro). Shannon's information index $(H)$ and Nei's gene diversity (h) were 0.281 and 0.176 , respectively, for the Alvor population and 0.356 and 0.234 for the Faro population. Overall, genetic variation within $R$. decussatus populations was high. The total genetic diversity $\left(H_{\mathrm{T}}\right)$ was explained by a low variation between populations $\left(G_{\mathrm{ST}}=0.145\right)$, which is consistent with high gene flow $\left(N_{\mathrm{m}}=2.9\right)$. The analysis
\end{abstract}

Communicated by H.-D. Franke.

J. C. Pereira $\cdot$ R. Chaves $(\bowtie) \cdot$ H. Guedes-Pinto

Institute for Biotechnology and Bioengineering,

Centre of Genomics and Biotechnology,

University of Trás-os-Montes and Alto Douro,

IBB-CGB/UTAD, 5001-801 Vila Real, Portugal

e-mail: rchaves@utad.pt

J. C. Pereira

e-mail: jorgecpereira@ portugalmail.pt

R. Chaves

Department of Genetics and Biotechnology,

UTAD, 5001-801 Vila Real, Portugal

A. Leitão · D. Matias

Instituto Nacional de Recursos Biológicos (INRB/L-IPIMAR),

Av. 5 de Outubro, 8700-305 Olhão, Portugal of molecular variance (AMOVA) showed that $65 \%$ of variability is within populations and $35 \%$ between populations $\left(\Phi_{\mathrm{PT}}=0.345 ; P \geq 0.001\right)$. The value of Nei's genetic distance was 0.0881 , showing a low degree of population genetic distance, despite the different geographic origin. This is the first study on the population genetics of $R$. decussatus by RAPD technique. The results may be useful for restocking programs and aquaculture.

Keywords RAPDs - Ruditapes decussatus .

Genetic diversity $\cdot$ Genetic differentiation

$\begin{array}{ll}\text { Abbreviations } \\ \text { RAPDs } & \text { Random amplified polymorphic DNA } \\ \text { PCR } & \text { Polymerase chain reaction } \\ \text { PBS } & \text { Phosphate-buffered saline solution } \\ \text { s } & \text { Seconds } \\ \text { min } & \text { Minutes } \\ \text { dNTPs } & \text { Deoxyribonucleotide triphosphate } \\ \text { bp } & \text { Base pair }\end{array}$

\section{Introduction}

The grooved carpet shell clam, Ruditapes decussatus, is widely distributed along the coastal and estuarine areas of Europe and North Africa. In Portugal, R. decussatus is among the most common clam species found in the market for human consumption and the one with the highest economic importance. Its market price can reach four times the price of other clam species (Fernández et al. 2000). About $80 \%$ of shellfish production originates from aquaculture, which is based on seed collected from natural recruitment 
banks and planted by producers in ongrowing parks (Matias et al. 2009). In spite of the species' great commercial importance, studies on the genetic diversity are very scarce, regarding only to allozymes (Worms and Pasteur 1982; Jarne et al. 1988; Borsa et al. 1991; Borsa et al. 1992; Jordaens et al. 2000). A sustainable exploitation of the natural resource and improvement in aquaculture requires a deeper knowledge of the genetic variability and genetic relationships of the different clam populations.

The classical strategies for the evaluation of genetic variation, such as morphology and embryology, have been outdated by the availability of molecular markers techniques (Weising et al. 1995). In general, molecular markers are based on polymorphisms found in DNA. The values obtained will be different for each individual, population or species, depending of the resolution of the DNA markers used. One of the molecular markers technique currently used is the random amplified polymorphic DNA (RAPD) (Williams et al. 1990; Welsh and McClelland 1990) that provides a useful tool to study the genetic variability of a population. This technique consists in the PCR (polymerase chain reaction) amplification of small, inverted repeats scattered in the genome, using a single, short primer of arbitrary sequence, allowing a scan throughout the genome, more randomly than the conventional techniques. The ability to examine genomic variation without previous sequence information (Williams et al. 1990), the relatively low cost of the technique and the requirement of only some nanograms of template DNA represent the major advantages of the use of RAPD technique in population studies. RAPDs have showed to be an extremely sensitive method for detecting DNA variation and for the establishment of genetic relationships between closely related organisms (Péres et al. 1998). Among the multiple applications of RAPDs are their use in population genetic studies (Haig et al. 1994), taxonomy (Chapco et al. 1992), determination of paternity (Lewis and Snow 1992) and mapping (Michelmore et al. 1991). The two main and often mentioned disadvantages of this type of molecular markers are a lack of reproducibility and the loss of complete genotypic information, due to the fact that most RAPD bands are dominantly inherited. The potential use of RAPD analysis in phylogenetic studies and population genetics has been documented in a wide variety of organisms (Hadrys et al. 1992). In marine invertebrates, this technique has successfully been used in analysing genetic polymorphisms at the interspecific level in oysters (Klinbunga et al. 2000) and mussels (Rego et al. 2002) and at the intraspecific level in scallops (Patwary et al. 1994), abalone (Huang et al. 2000) and oysters (Hirschfeld et al. 1999; Klinbunga et al. 2001).

In the present study, RAPD profiling was applied to measure the genetic diversity and interpopulational differentiation of two Portuguese populations of the clam $R$. decussatus.

\section{Materials and methods}

Sample collection and DNA extraction

Ruditapes decussatus individuals were collected from two Portuguese populations, 25 individuals from Ria Formosa (Faro: $37^{\circ} 2^{\prime} 0^{\prime \prime} \mathrm{N}, 7^{\circ} 55^{\prime} 0^{\prime \prime} \mathrm{W}$ ) and 25 individuals from Ria de Alvor (Alvor: $37^{\circ} 8^{\prime} 0^{\prime \prime} \mathrm{N}, 8^{\circ} 36^{\prime} 0^{\prime \prime} \mathrm{W}$ ), Algarve, south of Portugal. After two days of depuration, the material was dissected and kept in $70 \%$ ethanol, until further use. The protocol for DNA extraction followed the one by Pereira (2008), where 5-25 mg of adductor muscle was placed in a 2-ml eppendorf, with $100 \mu \mathrm{l}$ of $1 \times$ PBS and distilled water for 10 min each. The tissue was cut in small pieces and homogenized with a Pestle Pellet (Sigma). Afterwards, $180 \mu \mathrm{l}$ MDT (Tissue Lysis Buffer) and $20 \mu \mathrm{l}$ EDT (Proteinase K) were added and the samples were incubated overnight at $55^{\circ} \mathrm{C}$ for complete digestion. After centrifugation at $10000 \mathrm{rpm}$, for $3 \mathrm{~min}$, at room temperature, the supernatant was transferred to a new 2-ml eppendorf. The subsequent addition of $180 \mu \mathrm{l}$ LDT (Lysis Buffer) was followed by a 15 -s vortexing, and a flash spins down. After incubation at $70^{\circ} \mathrm{C}$ for $10 \mathrm{~min}, 240 \mu \mathrm{l}$ of absolute ethanol was added and the tubes were vortexed and spinned down. Finally, the lysate was transferred to a cartridge of the automatic nucleic-acid isolation system QuickGene-800, and the "DNA tissue mode" was selected.

\section{PCR amplification}

Several experiments were made to optimize the reproducibility of the RAPD assay, closely following the protocol of Williams et al. (1990), in which concentrations of template DNA, dNTPs, $\mathrm{MgCl}_{2}$ concentration and Taq polymerase were varied to determine which conditions produced the strongest and most reproducible patterns. Amplification reactions were performed in volumes of $25 \mu$ l containing $50 \mathrm{ng}$ of genomic template DNA, $100 \mu \mathrm{M}$ of each dATP, $\mathrm{dCTP}, \mathrm{dGTP}$ and dTTP, $0.2 \mu \mathrm{M}$ of the primer and 0.5 units of Taq DNA polymerase (Fermentas, Life Sciences). Amplification was performed in a Thermal Cycler (T-personal, Biometra) in a total of 45 cycles: $1 \mathrm{~min}$ at $94^{\circ} \mathrm{C}$, $1 \mathrm{~min}$ at $30-36^{\circ} \mathrm{C}$ and $2 \mathrm{~min}$ at $72^{\circ} \mathrm{C}$. The total volume of the PCR products was evaluated in $2 \%$ agarose gels and visualized by ethidium bromide staining. After electrophoresis, DNA bands profiling was observed under UV light and the images were saved in a gel analyser (UVIDOC). 
Data analysis

The genetic diversity within populations and the genetic differentiation between populations were quantified using GeneAlEx 6.1, Genetic Analysis Software (Peakall and Smouse 2006) and POPGENE (Yeh et al. 1997) programs. The genetic diversity within populations was estimated by calculating percentage polymorphic loci $(\% P)$, number of expected alleles $\left(n_{\mathrm{a}}\right)$, effective allele number $\left(n_{\mathrm{e}}\right)$, Nei's gene diversity (Nei 1973) $(h)$, Shannon's information index $(H)$, total gene diversity $\left(H_{\mathrm{T}}\right)$ and average gene diversity within populations $\left(H_{\mathrm{S}}\right)$.

In order to estimate the genetic differentiation between populations, analogues of $F_{\mathrm{ST}}$ fixation index measures such as coefficient of gene differentiation $\left(G_{\mathrm{ST}}\right)$ (Nei 1987) and $\Phi_{\text {PT }}$ (AMOVA) were used. The analysis of molecular variance (AMOVA) was calculated with the software GeneAlEx 6.1 (Peakall and Smouse 2006) for variation among individuals within populations and between populations. Due to the absence of assumptions, AMOVA is widely applicable and powerful. The fact that allele frequencies are not calculated led to the application of this method to analyse dominant data type, like RAPDs (Huff et al. 1983). The values of gene flow $\left(N_{\mathrm{m}}\right)$ (McDonald and McDermott 1993) and standard genetic distance of Nei (1972) were estimated.

\section{Results}

Genetic diversity within populations

The application of RAPD technique to the genome of Ruditapes decussatus produces a significant number of amplified fragments. Of the twenty screened primers, ten amplified 245 clear and reproducible bands (Table 1). One hundred and sixty-eight bands were amplified in the Alvor population and 183 in the Faro population (Fig. 1), with lengths ranging from 180 to $1,500 \mathrm{bp}$. The primer OPE-15 generated the highest number of bands ( 21 bands in the Alvor population and 24 in the Faro population); primer OPE-02 in the Faro population and primers OPE-01 and OPE-16 in the Alvor population produced the lowest number of bands/markers (Table 1). The two populations have 62 (Alvor) and 77 (Faro) private bands, respectively.

A summary of the genetic diversity of the populations based on the RAPD markers is presented in Table 2. Since dominant data have some shortcomings in the calculation of genetic diversity (Lowe et al. 2004), the method developed by Lynch and Milligan (1994) present in GeneAlEx 6.1 Genetic Analysis Software (Peakall and Smouse 2006) was used to calculate allele frequencies. The percentage of polymorphism $(\% P)$ of the two Portuguese populations was $68.57 \%$ (Alvor) and $73.88 \%$ (Faro), while the number of expected alleles $\left(n_{a}\right)$ and the number of effective alleles $\left(n_{\mathrm{e}}\right)$ were 1.371 and 1.267 for the Alvor and 1.486 and 1.389 for the Faro population. Nei's gene diversity index $(h)$ and Shannon's information index $(H)$ were estimated for the two populations of $R$. decussatus: the Alvor population showed the values of 0.176 and 0.281 , while the values for the Faro population were 0.234 and 0.356 .

\section{Population genetic structure}

Genetic diversity based on all bands showed that the total gene diversity $\left(H_{\mathrm{T}}\right)$, measured in terms of the total expected heterozygosity, was 0.2396 , the gene diversity within populations $\left(H_{\mathrm{S}}\right)$ was 0.2047 , and gene diversity between populations $\left(D_{\mathrm{ST}}=H_{\mathrm{T}}-H_{\mathrm{S}}\right)$ was 0.0349 (Table 3 ). Using these diversity indices, it was possible to calculate the coefficient of gene differentiation $\left(G_{\mathrm{ST}}=D_{\mathrm{ST}} / H_{\mathrm{T}}=\right.$ 0.1450 ), which measures the proportion of total genetic diversity occurring between populations and is analogous to
Table 1 Selected primers for the evaluation of genetic diversity in the two populations of Ruditapes decussatus

\begin{tabular}{|c|c|c|c|c|c|c|}
\hline \multirow[t]{2}{*}{ Name } & \multirow[t]{2}{*}{ Sequence $\left(5^{\prime}-3^{\prime}\right)$} & \multirow[t]{2}{*}{$T\left({ }^{\circ} \mathrm{C}\right)$} & \multicolumn{2}{|l|}{ Alvor } & \multicolumn{2}{|l|}{ Faro } \\
\hline & & & $\begin{array}{l}\text { Number } \\
\text { of bands }\end{array}$ & $\begin{array}{l}\text { Range } \\
\text { of bands }\end{array}$ & $\begin{array}{l}\text { Number } \\
\text { of bands }\end{array}$ & $\begin{array}{l}\text { Range } \\
\text { of bands }\end{array}$ \\
\hline OPE-01 & CCCAAGGTCC & 33 & 12 & $250-900$ & 20 & $380-1,500$ \\
\hline OPE-02 & GGTGCGGGAA & 36 & 15 & $300-880$ & 10 & $520-1,200$ \\
\hline OPE-03 & CCAGATGCAC & 36 & 17 & $300-880$ & 16 & $350-1,100$ \\
\hline OPE-06 & AAGACCCCTC & 36 & 22 & $250-1,500$ & 17 & $250-1,100$ \\
\hline OPE-10 & CACCAGGTGA & 36 & 17 & $250-1,300$ & 23 & $250-1,500$ \\
\hline OPE-11 & GAGTCTCAGG & 36 & 17 & $180-1,200$ & 18 & $180-1,300$ \\
\hline OPE-12 & TTATCGCCCC & 33 & 15 & $280-750$ & 12 & $380-950$ \\
\hline OPE-14 & TGCGGCTGAG & 33 & 20 & $320-1,000$ & 21 & $250-1,000$ \\
\hline OPE-15 & ACGCACAACC & 33 & 21 & $200-800$ & 24 & $180-1,000$ \\
\hline OPE-16 & GGTGACTGTG & 36 & 12 & $320-850$ & 21 & $200-1,500$ \\
\hline
\end{tabular}




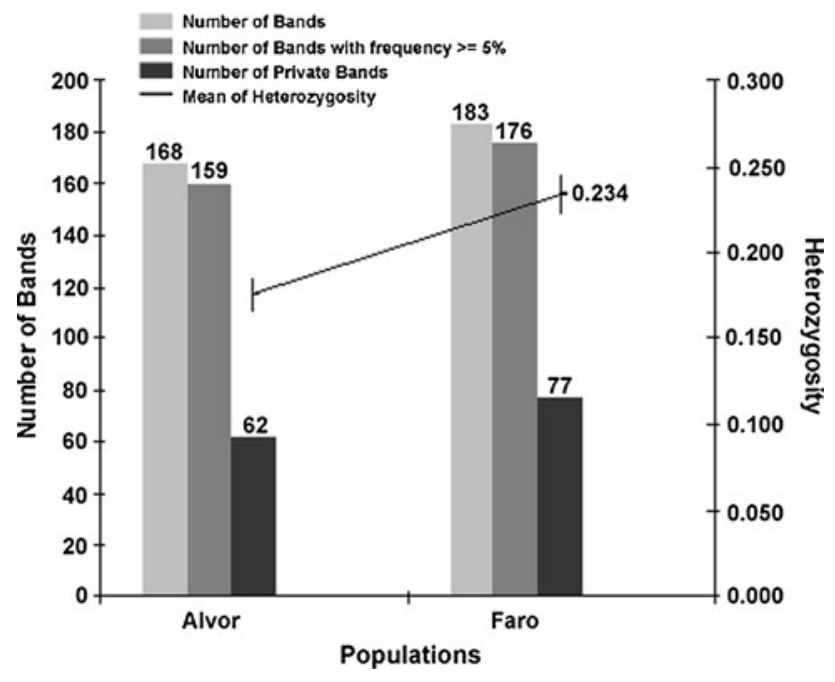

Fig. 1 Number of bands and mean heterozygosity in two Ruditapes decussatus populations

Table 2 Genetic variation within two Portuguese populations of Ruditapes decussatus

\begin{tabular}{llllllll}
\hline & $N$ & & $n_{\mathrm{a}}$ & $n_{\mathrm{e}}$ & $h$ & $H$ & $\% P$ \\
\hline Alvor & 25 & Mean & 1.371 & 1.267 & 0.176 & 0.281 & 68.57 \\
& & SE & 0.059 & 0.018 & 0.010 & 0.1654 & \\
Faro & 25 & Mean & 1.486 & 1.389 & 0.234 & 0.356 & 73.88 \\
& & SE & 0.056 & 0.023 & 0.012 & 0.017 & \\
Total & 50 & Mean & 1.429 & 1.328 & 0.205 & 0.319 & 71.22 \\
& & SE & 0.041 & 0.015 & 0.008 & 0.011 & \\
\hline
\end{tabular}

$N$ number of sampled individuals, $n_{a}$ number of expected alleles, $n_{e}$ effective allele number, $h$ Nei's gene diversity, $H$ mean Shannon's information index; $\% P$ percentage polymorphic loci calculated with all alleles included, $S E$ standard error

Wright's $F_{\mathrm{ST}}$ values. This means that only approximately $14.5 \%$ of the genetic variation observed in this study was due to differentiation between populations, while $85.5 \%$ is due to variation within populations,

Estimates of $G_{\mathrm{ST}}$ also allow to estimate another genetic parameter, the gene flow $\left[N_{\mathrm{m}}=0.5\left(1-G_{\mathrm{ST}}\right) / G_{\mathrm{ST}}\right]$ (McDonald and McDermott 1993), which was calculated to $N_{\mathrm{m}}=2.9$. According to Crow and Aoki (1984), gene flow values of $N_{\mathrm{m}}<1$ should be interpreted as little or no gene flow. Thus, the value of $N_{\mathrm{m}}=2.9$ would suggest high genetic exchange between the two populations studied.

AMOVA (analysis of molecular variance) (Table 4) showed that $65 \%$ of the variability was within populations whilst $35 \%$ was between them. Analogue to Wright's $F_{\mathrm{ST}}$ is also the $\Phi_{\mathrm{PT}}$ value, estimated with AMOVA; it amounted to 0.345 ( $P \geq 0.001$ ), based on permutation across the full data set.
Table 3 Genetic variation between the Portuguese populations of Ruditapes decussatus, based on the diversity indices of Nei (1973)

\begin{tabular}{lll}
\hline$H_{\mathrm{T}}$ & Total gene diversity & 0.2396 \\
$H_{\mathrm{S}}$ & Gene diversity within populations & 0.2047 \\
$D_{\mathrm{ST}}$ & Gene diversity between populations & 0.0349 \\
$G_{\mathrm{ST}}$ & Coefficient of gene differentiation & 0.1450 \\
$N_{\mathrm{m}}$ & Gene flow & 2.9 \\
\hline
\end{tabular}

Table 4 Analysis of molecular variance (AMOVA) in the two Portuguese populations of Ruditapes decussatus

\begin{tabular}{lrrrl}
\hline Source & $d f$ & SS & Variance $(\%)$ & Fixation index $\left(\Phi_{\mathrm{PT}}\right)$ \\
\hline Between pops & 1 & 463.320 & \multicolumn{1}{l}{35} & 0.345 \\
Within pops & 48 & 1569.520 & 65 & \\
Total & 49 & 2032.840 & 100 & \\
\hline
\end{tabular}

To compare the degree of genetic differentiation between populations, the standard genetic distance of Nei (1972) was estimated. The value of Nei's genetic distance was $D=0.0881$, while the value of genetic identity was $I=0.9157$, indicating low genetic differentiation between the two populations.

\section{Discussion}

RAPD assay was used in order to analyse the genetic diversity and differentiation in two southern Portuguese populations of Ruditapes decussatus. The technique was found to be effective in revealing polymorphisms in this species, since all 10 random primers produced at least one polymorphic fragment. The major limitations of this technique are its lack of reproducibility (Ford-Lloyd and Painting 1996; Weising et al. 1995; Guadagnuolo et al. 2001) and its sensitivity to small variations in PCR conditions. In order to overcome these limitations, DNA of high quality was used and three repetitions were performed for the same primers and individuals which generate the same results.

Genetic diversity within populations is of great concern to ecologists and geneticists. A reduced genetic variation is thought to affect the ability of populations to adapt to changing environments, thereby increasing their probability of extinction (Beardmore 1983). Waugh and Powell (1992) stated that the analysis of polymorphism by molecular markers could help to select priority areas for conservation and provide vital information for the development of genetic sampling and improvement. 
In total, the analysis of the genetic variability within populations by RAPDs based on percentage of polymorphic loci $(\% P)$, effective allele numbers $\left(n_{\mathrm{a}}\right)$, expected numbers of alleles $\left(n_{\mathrm{e}}\right)$, Nei's gene diversity $(h)$ and Shannon's Index $(H)$ suggests that the two populations present very high levels of genetic diversity. These results are similar to those by Borsa and Thiriot-Quievreux (1990), Borsa et al. (1992), Passamonti et al. (1997) and Jordaens et al. (2000) who studied the populations of this species, especially the Azores population, using allozymes as molecular markers. The high levels of genetic variation suggest that these bivalves are phenotypically plastic and may respond adequately to changing environments. In contrast, very low genetic differentiation was found between the two studied populations. Only $14.5 \%$ $\left(G_{\mathrm{ST}}=0.145\right)$ of the genetic variability was between populations, while $85.5 \%$ was within populations. The gene flow $\left(N_{\mathrm{m}}\right)$ value (Slatkin 1993) allows evaluating whether or not each of the considered population of a species evolves as an independent unit. Theory predicts that a global value of $N_{\mathrm{m}}>1$ prevents random differentiation by genetic drift (Slatkin 1993). The calculated level of gene flow $\left(N_{\mathrm{m}}=2.9\right)$ would allow the two populations to act as a single interbreeding population. However, this conclusion should be considered cautiously because the mathematical assumptions underlying the estimates of genetic diversity and differentiation may not be completely realistic (Whitlock and McCauley 1999). Similar results were obtained with the method of analysis of molecular variance (AMOVA) that showed a high genetic variation within populations and low genetic differentiation between them. However, the value of fixation index $\left(\Phi_{\mathrm{PT}}=0.345\right)$ suggested that the populations may have some structure, although the degree of differentiation was not large. This differentiation may be due to geographical isolation or hydrological factors.

The values of the distance and genetic identity (Nei 1972) estimated for the two populations were 0.9176 and 0.0860 , respectively. These values support the high degree of genetic identity and the low level of genetic differentiation of the two populations.

In conclusion, the two populations of $R$. decussatus studied the presented high values of genetic variability within populations and low values of genetic differentiation between them, demonstrating a high degree of genetic homogeneity. The value of the gene flow $\left(N_{\mathrm{m}}\right), G_{\mathrm{ST}}$ and $\Phi_{\mathrm{PT}}$ quantification demonstrates that the exchange of genes between the two populations is high. A high degree of genetic homogeneity among populations has also been described for the populations of other marine invertebrates, such as Concholepas concholepas (Gallardo and Carrasco 1996), Ostrea chilensis (Toro and Aguila 1996) and Venus antique (Gallardo et al. 1998). The high values found for the genetic diversity within populations, associated with low values of genetic variation between populations, suggest panmixy as the dominant mode of reproduction (Armbruster 1997, 1998; Fernández-Tajes et al. 2007).

Mollusc species with extended larval planktonic phases are generally thought to disperse further and to show higher rates of gene flow, larger geographic ranges, lower levels of genetic differentiation between populations and high levels of genetic variation within populations (Scheltema and Williams 1983; Waples 1987; Williams and Benzie 1993; Palumbi 1995). The life cycle of $R$. decussatus presents a larval planktonic stage, which lasts about three weeks, followed by benthic juvenile and adult stages. During the larval phase, larvae can travel many miles driven by currents before settling in favourable habitats.

Due to overexploitation, the $R$. decussatus population at Alvor suffered a strong decline. This led to a restocking by man for commercial purposes with seed from other local populations, mainly from the Ria Formosa population, which is the most important source of $R$. decussatus natural seed (juveniles) for these activities. The dispersal of planktonic larvae as well as the introduction of Ria Formosa seed in the Alvor population may have contributed to the low values of genetic differentiation between these two populations. These results can be very useful in designing programmes for the management of marine resources. Furthermore, studies on the genetic variability of $R$. decussatus should be extended to a larger number of local population using other types of molecular markers in order to provide a broader scientific for defining the best practices to improve a sustainable aquaculture production.

Acknowledgments This work was supported by a $\mathrm{PhD}$ grant Ref. SFRH/BD/27720/2006, a research project Ref. PTDC/MAR/72163/ 2006 (European Union with a research project Ref. FCOMP-01-0124FEDER-007384) and the "Programa Ciência 2007/2008" of the Science and Technology Foundation (FCT) from Portugal. We also wish to thank the IPIMAR/Tavira, Portugal team for their local support in sampling and to the referee for valuable comments that greatly improved the manuscript.

\section{References}

Armbruster G (1997) Genetische Verarmung aufgrund von Populationseinbrüchen: Eine Analyse bei der seltenen Landschneckenart Cochlicopa ninens (Gallenstein, 1848). Nature Landscape 72:444-446

Armbruster G (1998) Bei einer verbreiteten Landschnecke Cochlicopa lubrica (O. F. Müller), wird die Frequenz von molekularen phänotypen durch Selbstbefruchtung und habitatspezifische Selektion beeinflusst. Laufener Seminarbeiträge 2/98 der Bayerischen Akademie Naturschutz und Landschaftspflege (ANL) $39-49$

Beardmore JA (1983) Extinction, survival, and genetic variation. In: Schoenwald-Cox CM, Chambers SM, MacBryde B, Thomas L (eds) Genetics and conservation. Benjamin-Cummings, Menlo Park, CA, pp 125-151 
Borsa P, Thiriot-Quievreux C (1990) Karyological and allozymic characterization of Ruditapes philippinarum, $R$. aureus and $R$. decussatus (Bivalvia, Veneridae). Aquaculture 90:209-227

Borsa P, Zainui M, Delay B (1991) Heterozygote deficiency and population structure in the bivalve Ruditapes decussatus. Heredity $66: 1-18$

Borsa P, Jousselin Y, Delay B (1992) Relationships between allozymic heterozygosity, body size, and survival to natural anoxic stress in the palourde Ruditapes decussatus (Bivalvia: Veneridae). J Exp Mar Biol Ecol 155:169-181

Chapco W, Kelln RA, McFadyen DA (1992) Intraspecific mitochondrial DNA variation in the migratory grasshopper, Melanoplus sanguinipes. Heredity 69:547-557

Crow JF, Aoki K (1984) Group selection for polygenic behavioral trait: estimating the degree of population subdivision. Proc Natl Acad Sci USA 81:6073-6077

Fernández A, García T, Asensio L, Rodríguez MÁ, González I, Céspedes A, Hernández PE, Martín R (2000) Identification of the clam species Ruditapes decussatus (Grooved Carpet Shell), Venerupis pullastra (Pullet Carpet Shell) and Ruditapes philippinarum (Japanese Carpet Shell) by PCRRFLP. J Agric Food Chem 48:3336-3341

Fernández-Tajes J, Gaspar M, Martínez-Patiño D, McDonough N, Roberts D, González-Tizón A, Martínez-Lage A, Méndez J (2007) Genetic variation of the razor clam Ensis siliqua (Jeffreys, 1875) along the European coast based on random amplified polymorphic DNA markers. Aquac Res 38:1205-1212

Ford-Lloyd B, Painting K (1996) Measuring genetic variation using molecular markers. IPGRI, Rome

Gallardo M, Carrasco J (1996) Genetic cohesiveness among population of Concholepas concholepas (Gastropoda, Muricidae) in southern Chile. J Exp Mar Biol Ecol 197:237-249

Gallardo M, Penaloza L, Clasing E (1998) Gene flow and allozymic population structure in the clam Venus antique (King \& Broderip), (Bivalvia, Veneriidae) from southern Chile. J Exp Mar Biol Ecol 230:193-205

Guadagnuolo R, Savova-Bianchi D, Felber F (2001) Gene flow from wheat (Triticum aestivum L.) to jointed goatgrass (Aegilops cylindrica Host.), as revealed by RAPD and microsatellite markers. Theor Appl Genet 103:1-8

Hadrys H, Balick M, Schierwater B (1992) Applications of randomly amplified polymorphic DNA (RAPD) in molecular ecology. Mol Ecol 1:55-63

Haig SM, Rhimer JM, Heckel DG (1994) Population differentiation in randomly amplified polymorphic DNA of red-cocked woodpeckers Picoides borealis. Mol Ecol 3:581-595

Hirschfeld D, Dhar AK, Rask K, Alcivar-Warren A (1999) Genetic diversity in the eastern oyster (Crassostrea virginica) from Massachusetts using RAPD technique. J Shellfish Res $18: 121-125$

Huang BX, Peakall R, Hanna PJ (2000) Analysis of genetic structure of blacklip abalone (Haliotis rubra) populations using RAPD, minisatellite and microsatellite markers. Mar Biol 136:207-216

Huff DR, Peakall R, Smouse PE (1983) RAPD variation within and among natural populations of outcrossing buffalograss [Buchloe dactyloides (Nutt.)]. Theor Appl Genet 86:927-934

Jarne P, Berrebi P, Guelorget O (1988) Variabilité génétique et morphometrique de cinc populations de la palourde Ruditapes decussatus (mollusque, bivalve). Oceanol Acta 11:401-407

Jordaens K, De Wolf H, Willems T, Van Dongen S, Brito C, Frias Martins AM, Backeljau T (2000) Loss of genetic variation in a strongly isolated Azorean population of the edible clam, Tapes decussates. J Shellfish Res 19:29-34

Klinbunga S, Ampayup P, Tassanakajon A, Jarayabhand P, Yoosukh W (2000) Development of species-specific markers of the tropical oyster (Crassostrea belcheri) in Thailand. Mar Biotechnol 2:476-484

Klinbunga S, Ampayup P, Tassanakajon A, Jarayabhand P, Yoosukh W (2001) Genetic diversity and molecular markers of cupped oysters (Genera Crassostrea, Saccostrea and Striostrea) in Thailand revealed by RAPD analysis. Mar Biotechnol 3:133-144

Lewis PO, Snow AA (1992) Deterministic paternity exclusion using RAPD markers. Mol Ecol 1:155-160

Lowe AJ, Harris SA, Ashton P (2004) Ecological genetics: design, analysis and application. Blackwell, Oxford

Lynch M, Milligan BG (1994) Analysis of population genetic structure with RAPD markers. Mol Ecol 3:91-99

Matias D, Joaquim S, Leitão A, Massapina C (2009) Effect of geographic origin, temperature and timing of broodstock collection on conditioning, spawning success and larval viability of Ruditapes decussatus (Linné, 1758). Aquac Int 17:257-271

McDonald BA, McDermott JM (1993) Population genetics of plant pathogenic fungi. Bioscience 43:311-319

Michelmore RW, Paran I, Kesseli RV (1991) Identification of markers linked to disease resistance genes by bulked segregant analysis: a rapid method to detect markers in specific regions by using segregating populations. Proc Natl Acad Sci USA 88:9828-9832

Nei M (1972) Genetic distance between populations. Am Nat 106:283-292

Nei M (1973) Analysis of gene diversity in subdivided populations. Proc Natl Acad Sci USA 70:3321-3323

Nei M (1987) Molecular evolutionary genetics. Columbia University Press, New York, p 512

Palumbi SR (1995) Using genetics as an indirect estimator of larval dispersal. In: McEdwards L (ed) Ecology of marine invertebrate larvae. CRC Press Inc, Boca Raton, pp 369-387

Passamonti M, Mantovania B, Scalia V (1997) Allozymic characterization and genetic relationships among four species of Tapetinae (Bivalvia, Veneridae). Ital J Zool 64(2):117-124

Patwary MU, Kenchington EL, Bird CJ, Zouros E (1994) The use of random amplified polymorphic DNA markers in genetic studies of the sea scallop Placopecten magellanicus (Gmellin, 1791). J Shellfish Res 13:547-553

Peakall R, Smouse PE (2006) GENEALEX 6: genetic analysis in excel. Population genetic software for teaching and research. Mol Ecol Notes 6:288-295

Pereira J (2008) Perfis de RAPD-PCR em populações de Ruditapes decussatus (Linnaeus, 1758) do sul de Portugal: Avaliação da diversidade genética. Master thesis

Péres T, Albornoz J, Domínguez A (1998) An evaluation of RAPD fragment reproducibility and nature. Mol Ecol 7:1347-1357

Rego I, Martínez A, González-Tizón A, Vieites J, Leira F, Méndez J (2002) PCR technique for identification of Mussel species. J Agric Food Chem 50(7):1780-1784

Scheltema RS, Williams IP (1983) Long distance dispersal of planktonic larvae and the biogeography and evolution of some polynesian and western pacific mollusks. Bull Mar Sci 33:545-565

Slatkin M (1993) Isolation by distance in equilibrium and nonequilibrium populations. Evolution 47:264-279

Toro J, Aguila P (1996) Genetic differentiation of populations of the oyster Ostrea chilensis in Southern Chile. Aquat Living Resour 9:75-78

Waples RS (1987) A multispecies approach to the analysis of gene flow in marine shore fishes. Evolution 41:385-400

Waugh R, Powell W (1992) Using RAPD markers for crop improvement. Trends Biotechnol 10:186-191

Weising K, Nybom H, Wolff K, Meyer W (1995) DNA fingerprinting in plants and fungi. CRC Press, London 
Welsh J, McClelland M (1990) Fingerprinting genomes using PCR with arbitrary primers. Nucleic Acids Res 18:7213-7218

Whitlock MC, McCauley DE (1999) Indirect measures of gene flow and migration: $\mathrm{F}_{\mathrm{ST}}$ doesn't equal $1 /(4 \mathrm{Nm}+1)$. Heredity $82: 117-125$

Williams ST, Benzie JAH (1993) Genetic consequences of long larval life in the starfish Linckia laevigata (Echinodermata: Asteroidea) on the Great Barrier Reef. Mar Biol 117:71-77

Williams JGK, Kubelik AR, Livak KJ, Rafalski JA, Tingey SV (1990) DNA polymorphisms amplified by arbitrary primers are useful as genetic markers. Nucleic Acids Res 18:6531-6535
Worms J, Pasteur N (1982) Polymorphisme biochimique de la palourde, Venerupis decussata, de 1'étang du Pévost (France). Oceanol Acta 5:395-397

Yeh FC, Yang RC, Boyle TBJ, Ye ZH, Mao JX (1997) POPGENE, the user-friendly shareware for population genetic analysis. Molecular Biology and Biotechnology Centre, University of Alberta, Canada 